\title{
Entrepreneurial tendencies of migrants working in the care sector in Poland
}

\author{
Jolanta Maj, Sabina Kubiciel-Lodzińska
}

\section{A B S T R A C T}

Objective: The main goal of the paper is to assess the degree of intent to become entrepreneurial, and whether this intent influences perceived barriers and hindrances self-employment.

Research Design \& Methods: For the purpose of the study, we employed the approach of grounded theory. The sample included 42 immigrants from the care sector chosen in accordance with snowball sampling and Respondent Driven Sampling.

Findings: Most immigrants did not think about setting up a business or rejected the idea due to various reasons, including their current legal status or the lack of financial resources, sufficient language, and professional competencies. Some of the respondents admitted that they would like to start their own business in the future.

Implications \& Recommendations: The implications include the identification of barriers perceived by immigrants, which may be an indicator for decision-makers about areas which require improvement in order to facilitate migrant entrepreneurship.

Contribution \& Value Added: The article contributes to the research on migrant entrepreneurship by analysing entrepreneurial tendencies of migrants working in a specific yet important sector and by showing novel causalities between psychological, social, and environmental factors and the degree of intent to become self-employed.

\begin{tabular}{llll}
\hline Article type: & research article \\
Keywords: & $\begin{array}{l}\text { migrant entrepreneurship; migrant entrepreneur; migrant self-em- } \\
\text { ployment; care sector; entrepreneurship }\end{array}$ \\
JEL codes: & L26, O15, F22 & \\
\hline Received: 31 November 2019 & Revised: 16 May 2020 & Accepted: 28 May 2020 \\
\hline
\end{tabular}

Suggested citation:

Maj, J., \& Kubiciel-Lodzinska, S. (2020). Entrepreneurial tendencies of migrants working in the care sector in Poland. Entrepreneurial Business and Economics Review, 8(3), 27-46. https://doi.org/10.15678/EBER.2020.080302 


\section{INTRODUCTION}

Migrant entrepreneurship is an important socio-economic phenomenon, which became the object of interest of migration and management researchers and decision-makers (Kloosterman \& Rath, 2003; van Delft et al., 2000). Migrant entrepreneurs are defined as people who came to the country of immigration and started their own business (Chaganti \& Greene, 2002). This phenomenon occurs mostly in highly developed countries (Kloosterman \& Rath, 2003) which attract representatives of poorer nations. Starting own business is one of the forms enabling migrants to overcome obstacles in the host country's labour market (Waldinger et al., 1990). In the case of immigrants, sometimes opening own company is forced, because it is the only option to earn and the only possibility of staying in the country of immigration (Chrysostome, 2010). Research shows that immigrants are more likely to start their own businesses than non-immigrants (Fairlie, 2008). Companies founded by migrants usually fail more often than those established by citizens of a given country, which may result, among other things, from limited access to bank loans (Fraser, 2006), insufficient qualifications, or market mismatch in the new country. The functioning of migrant entrepreneurs is connected with additional challenges, such as language barrier, the understanding of the legal and institutional environment, consumer needs in the host country, access to capital, market situation, and competition (Glover \& Sim, 2002; Volery, 2007). Despite the significant number of studies concerning this phenomenon, we must be aware that the nature of migration-related issues is drastically changing (Dang \& Harima, 2020). In Poland, the mobility model has transformed from an emigration into an immigration model (Solga \& Kubiciel-Lodzinska, 2017). The relevance of immigrant labour workforce is growing, and its presence is crucial not only for the development of the industry but also for household services including elderly care. Demand for the latter is growing due to Poland's aging population. In Poland, the phenomenon of migrant entrepreneurship is starting to gain importance; however, there is relatively little research on this subject (Andrejuk, 2017a; Brzozowski, 2017; Czerniejewska, 2014; Glinka \& Brzozowska, 2015; Nestorowicz, 2013), and the conducted research focuses on already established enterprises.

The current article concentrates on (1) entrepreneurial intentions (2) in a specific, under-investigated segment of the immigrant population (working in elderly care) and (3) in an under-researched context (Poland).

The conducted research fills the theoretical gap regarding the tendencies to set up an own business among immigrants working in the care sector. We selected the care sector on purpose. The USA experience shows that $20 \%$ of immigrant enterprises operate in health care and social assistance (Fairlie \& Lofstrom, 2015), which proves that this could be an industry that stimulates entrepreneurship. Furthermore, due to brain waste (Hanson, 2006; Chiswick \& Miller, 2009) immigrants employed in the care sector are at risk of marginalisation. Becoming entrepreneurial is a way of escaping marginalisation and the grey economy, raise status on the labour market, better use qualifications, and in some cases to circumvent the inability of employment in "better" labour market segments. The analysis of willingness to establish a business among migrants working in senior care is important because illegal employment predominates in this sector. Reducing grey economy is beneficial from the viewpoint of the host country's economy, because legal workers 
pay taxes and social security contributions to the budget of the host country. This study contributes to the research on migrant entrepreneurship by analysing entrepreneurial tendencies of migrants working in a specific yet important sector by showing novel causalities between psychological, social, and environmental factors and the degree of intent to become an entrepreneur. First the study not only explores the intent to become an entrepreneur but also the combination of psychological, social, and environmental factors that contribute to the decision of becoming an entrepreneur.

The study aims to explore the research problem of the influence of the degree of intent to become entrepreneurial on the perceived barriers and hindrances to setting up a business. Therefore, we formulated the following research question: What are the motives for and perceived barriers and hindrances to become an entrepreneur for migrant elderly care workers in Poland?

The paper is organised in the following way. First, we present the results of a literature review on the issue of migrant entrepreneurship with focus on elderly care, followed by a materials and methods section that describes the sample selection, sample structure, the research tool and data collection process. Then, we explain and discuss the research results. The paper ends with conclusion, which including recommendations for further research.

\section{LITERATURE REVIEW}

Migrant entrepreneurship is recognised as an important issue for the development of regions and states. This phenomenon was studied in developed countries, but also in those considered undeveloped (Lofstrom, 2014), as immigrant entrepreneurs are also present on labour markets of developing countries (Elo, 2016). This shows that immigrant entrepreneurship can be interesting from an economic viewpoint, even when it is not massive in scale. Migrant entrepreneurship became the subject of analysis of different scientific disciplines around the world (Aliaga-Isla \& Rialp, 2013), analysed through the lens of different scientific approaches (Ilhan-Nas et al., 2011).

Research shows that several factors influence the migrant's intention to become an entrepreneur (Bird, 2015; Liñán \& Fayolle, 2015) and decision to set up a business, even the immigrant's country of origin. Research on this subject was conducted, among other places, in the United States of America (Raijman \& Tienda, 2000; Saxenian, 2002). Moreover, scholars examined the barriers and challenges in conducting business by immigrants (Constant \& Zimmermann, 2006; Teixeira et al., 2007) and determined that there are limitations stemming from cultural mismatches, the lack of experience and knowledge (Shinnar \& Young, 2008), the length of stay (Leicht et al., 2012), and difficulties with access to loans (Leicht \& Welter, 2009). Among the determinants of setting up a business, research scrutinises the immigrants mindset (Czerniejewska, 2014), education and experience in the labour market, and the existence of enclave markets (Le, 2000). Strategies and financial outcomes of migrant enterprises are also analysed. Bolzani and Boari (2018) analyse, among others, the export results of such companies, while Achidi Ndof and Priem (2011) overview strategies of immigrant ventures. Others determine that migrant enterprises achieve better results than native enterprises due to the access to international networks (Neville et al., 2014). Furthermore, it was noted that a certain process needs to be set into motion for an employee to evolve into an entrepreneur (Rahman, 2018; Wilpert, 2003). The key determinant of the decision to become self-employed for migrants is very often 
that entrepreneurship is perceived as the only way to overcome labour market barriers, such as low payed jobs, discrimination due to ethnic origin, and difficulties in the formal recognition of qualifications (Light $\&$ Gold, 2000). In general, the tendency to start a business among immigrants increases with the increase of their human, financial and social capital. Caparrós Ruiz (2010) indicates that immigrants are disadvantaged when entering into self-employment as the first job. This is connected with the need to have sufficient experience to run a business (Caparrós Ruiz, 2010). Research from Poland shows that the main driver for starting own business was the need for independence and raising own social status and income. A significant group plans on becoming entrepreneur even before coming to Poland (Brzozowski \& Pędziwiatr, 2014). Another area of analysis in the context of the development of migrant entrepreneurship are also language skills (Ram \& Smallbone, 2003). Australian and British research shows that the host country language proficiency positively impacts the migrants' decision to become entrepreneurial (Evans, 1989; Ram \& Smallbone, 2003). Furthermore, studies show that the level of language proficiency affects the choice of the industry in which a migrant entrepreneur operates (Rueda-Armengot \& Peris-Ortiz, 2012). Thus, one of our research goals is to determine the possible motives, hindrances and barriers of migrant's entrepreneurship.

A typology of economic structures of migrant entrepreneurships was distinguished within the mixed embeddedness model. Within those structures, scholarship distinguishes the post-industrial sector as the one with the most potential for development, requiring low qualifications and having low entering barriers (Kloosterman, 2010). This sector includes, among others, household services such as care services. The demand for such services is growing in highly developed countries, which witness an aging population (Brzozowski, 2019). As a result, this particular industry creates opportunities for the development of micro-entrepreneurship (Hall et al., 2019). This was one of the reasons to focus the following study on the care sector, narrowing the primary research goal on the motives and entrepreneurial tendencies of migrants working in the care sector. The sector which attracts migrant workers is the care sector and especially elderly care. The influx of immigrant workers is especially visible in developed countries, in which there appears a "care crisis," that is the inability to meet the demand with native care givers (Yeates, 2010). Native workers do not want to work in this sector due to the perceived low status (Goel \& Penman, 2015) and undesirability of this type of work (Hugo, 2009). Elderly care has become an area dominated by migrants, very often the undertaken employment is illegal (Van Hooren, 2010), and it provides difficult working conditions due to low wages and social isolation, which very often results from the round-the-clock care (Walsh \& O'Shea, 2010). Furthermore, research shows that self-employment is for migrants a way to escape marginalisation (Blume et al., 2009). Most of the current literature focuses on factors that attract and push out migrants into the elderly care sector (Bruquetas-Callejo, 2020), their scope of responsibilities (Martin et al., 2009), the changing role of the family (Rugolotto et al., 2017), or the changes in formal and institutional conditions (Pelzelmayer, 2016; Van Hooren, 2010). However, to our best knowledge, the entrepreneurial tendencies of migrants working in this sector have not analysed yet.

Research shows that high-skilled migrants very often undertake employment in jobs below their qualifications (Borjas, 1991, 1994; Baker \& Benjamin, 1994). Such a situation is 
defined as brain waste, and occurs when a person who incurred education costs does not benefit from the raised capital (Pires, 2015). Brain waste results from the fact that skills, qualifications, and professional experience are not being used in the incoming country (Chammartin, 2008), due to the lack of recognition of diploma and qualification from the home countries. In terms of not fully using qualifications by highly qualified migrants, scholars also employ the term "de-skilling," which means that migrants undertake employment not fitting their qualifications and professional experience. Difficulties with the recognition and transfer of skills and qualifications resulting from higher education are not uncommon (Brzozowski, 2008). Thus, the decision to become entrepreneurial is necessity-driven, as the only way to come out of illegal employment below one's qualifications (Hughes, 2003). Nonetheless, German research shows that self-employment in the care sector may have negative consequences for the migrant entrepreneur, as it may not result in improving working conditions nor increasing salary. Instead, it may result in increased obligations and risk related to the correct implementation of regulations, including tax regulations (Lutz \& Palenga-Möllenbeck, 2011). Austria is a special example, where regulations encourage selfemployment of migrants who want to work in elderly care. The so-called live-in caregivers, even if they have only one patient, can become self-employed (Schwiter et al., 2018).

Demographical changes in Europe, such as the decrease in work force and the growing number of older people result in the rising importance of immigrants and the elderly care they provide (Honig, 2018). We cannot rule out that migrants would perceive the possibility of becoming self-employed as a way to legalise their employment. On the other hand - in the case of nurses, physiotherapists - it would give them the opportunity to work in accordance with qualifications, not necessarily only in elderly care. Hence, it would be important to determine whether this would be necessity- or opportunity-driven, because each of these forms has a different impact on economic growth in the host country (Brzozowski et al., 2017).

\section{MATERIAL AND METHODS}

Adopting a social-constructivist perspective, 42 in-depth interviews were conducted among immigrants working in elderly care. For the purpose of the study, they were defined as people who permanently live with a dependent person or periodically take care of a senior and their household. The interviews were digitally recorded, transcribed and analysed using MAXQDA software. The interviews were conducted in Polish and lasted about 45 minutes. For the purpose of the study, we selected the grounded theory approach. The data was analysed using open and axial coding (Charmaz, 2006; Strauss \& Corbin, 1994; Strauss \& Corbin, 1997), which enabled the development of first and second order categories. To ensure the quality of the analysis, we employed the audit trial, collaboration, and disconfirming evidence validity procedures (Creswell \& Miller, 2000). The codes were developed using the inductive coding approach with iteration between theories and empirical material. This approach required several meetings between the authors separately coding the empirical material. After several iterations based on logical similarities and ontological levels of each code, particular categories were developed.

The structure of the sample has been presented in Table 1. The vast majority, 39 people came from Ukraine, two from Belarus, and one from Russia. The youngest person in the study group was 18 years old and the oldest was 57 years old. 
Table 1. The structure of the sample

\begin{tabular}{|l|c|c|}
\hline \multicolumn{2}{|c|}{ Respondent characteristics Indicator } & Number of respondents \\
\hline \multirow{2}{*}{ Gender } & Male & 8 \\
\cline { 2 - 3 } & Female & 34 \\
\hline \multirow{2}{*}{ Legal status } & Legal & 16 \\
\cline { 2 - 3 } & Illegal & 26 \\
\hline \multirow{2}{*}{ Country of origin } & Ukraine & 39 \\
\cline { 2 - 3 } & Other & 3 \\
\hline
\end{tabular}

Source: own study.

For the purpose of the study, two sampling techniques have been used: snowball sampling and Respondent Driven Sampling. Snowball sampling is based on a non-random selection of respondents for the study. After each interview, the interviewer asked the respondent to indicate the next person or more - as there is no limit in the number of people recruited by the respondent - with whom he could conduct interviews on the same subject. However, the interviewer usually attracted more people to research through own contacts. RDS (Respondent Driven Sampling) relies on a sample controlled by the respondent (Heckathorn, 1997). This is a modification of snowball sampling, supplemented by a double incentive system. After the interview the respondent could indicate a limited number of people for the study (a maximum of two people). This method allows the use of a dual system of incentives consisting of rewarding the respondent both for giving an interview (50 PLN for the conducted research) and for recruiting more people (30 PLN for the conducted research). Furthermore, when using snowball sampling, the interview is usually conducted at the location indicated by the respondent (the interviewer comes to the respondent). However, in the case of using the RDS method, the interview happens at the location set by the interviewer (the respondent comes to the interviewer). Using the RDS sampling method at a regional scale was a novelty because, so far, the method was used to analyse the migrant population in cities or agglomerations (Gorny \& Napierała, 2016). However, using RDS on a regional scale resulted in difficulties in achieving the assumed sample. The method was supplemented with the traditional snowball sampling. The choice of the sampling method did not influence the respondents' gender, education level, nature of work, and completeness of provided answers. Among the respondents selected using the RDS method, we observed a small overrepresentation of people treating elderly care as additional employment (14 to 11 ), students (3 to 1 ), and young people (average age 32.2 , while in the snowball sample the average age was 33.2). Furthermore, the RDS sample showed a higher representation of respondents living in larger cities, such as Opole, Brzeg, and Nysa, while in the snowball sample most respondents lived in the suburbs.

We used a semi-structured interview questionnaire. The aim of the research was not to develop generalisations but to reach for thoughts, experiences of interlocutors, and the explanation of motives favourable and unfavourable for undertaking entrepreneurial activity by immigrants currently working in providing care to the elderly. The conducted research was developed as exploratory research. 


\section{RESULTS AND DISCUSSION}

The first main finding shows that only individual migrants started an own business in Poland. In the conducted research only one respondent, no. 15, declared self-employment. However, several respondents stated that they would like to be self-employed in the future or at least consider such a possibility. For the purpose of further analysis, the respondents were divided based on the degree of intention to start own business. The division is presented in Table 2.

Table 2. Respondents' intention to start own business

\begin{tabular}{|l|l|}
\hline \multicolumn{1}{|c|}{ Degree of intention to start own business } & \multicolumn{1}{c|}{ Respondents } \\
\hline Already self-employed & $\mathrm{R} 15$ \\
\hline Intending to become an entrepreneur & $\begin{array}{l}\mathrm{R} 4, \mathrm{R} 5, \mathrm{R} 6, \mathrm{R} 8, \mathrm{R} 9, \mathrm{R} 10, \mathrm{R} 16, \mathrm{R} 17, \mathrm{R} 20, \mathrm{R} 24, \mathrm{R} 25, \mathrm{R} 29, \\
\mathrm{R} 37\end{array}$ \\
\hline Not intending to become an entrepreneur & $\mathrm{R} 7, \mathrm{R} 12, \mathrm{R} 13, \mathrm{R} 18, \mathrm{R} 23, \mathrm{R} 27, \mathrm{R} 30, \mathrm{R} 31, \mathrm{R} 33, \mathrm{R} 35, \mathrm{R} 36$ \\
\hline Has not thought about it & $\begin{array}{l}\mathrm{R} 1, \mathrm{R} 2, \mathrm{R} 3, \mathrm{R} 11, \mathrm{R} 14, \mathrm{R} 19, \mathrm{R} 21, \mathrm{R} 22, \mathrm{R} 26, \mathrm{R} 28, \mathrm{R} 32, \\
\mathrm{R} 34, \mathrm{R} 38, \mathrm{R} 39, \mathrm{R} 40, \mathrm{R} 41, \mathrm{R} 42\end{array}$ \\
\hline
\end{tabular}

Source: own study.

Most respondents have not considered setting up their own business and some - although admitting that they did not think about it - after a short reflection stated that they do not want to become entrepreneurial.

Most of the respondents who consider starting an own business in Poland, want to do it in a different sector, not connected with the care sector. Respondents mention the construction sector (Respondent no. 4), services (Respondent no. 6, 8, 16, 17, 20, 25), and gastronomy (Respondent no. 10). Entrepreneurial intentions depend on exogenous factors like the personal situation (Krueger, 2017).

Considering the reasons for starting a business in Poland, we observed a division between the respondent already self-employed and those who plan to become self-employed. Aware of the limitation of having only one respondent who already has an own business and, thus, unable to draw any representative conclusions, we observed the differences between the other groups and respondents. When explaining the motives for setting up a business, Respondent no. 15 mentioned two reasons: a perceived market gap and the fact that this form of employment was more suitable for the respondent in terms of remuneration, working hours, and legal conditions. The reasons were categorised as competency-related, because in this particular study we included personal preferences (attitudes) and market orientation (skills and knowledge). "Older people need the help of physiotherapists. You have many [older people] in Poland, but nobody is taking care of your elders .... I noticed that in Poland the elderly are neglected by their families" (Respondent no. 15). This confirms Curci and Mackoys (2010) results stating that migrant entrepreneurships may fill a niche in the local national economy.

The motives of the second group were summarised in Figure 1. We developed first and second order codes in accordance with Schwartz's human value structure (Schwartz, 1994). 


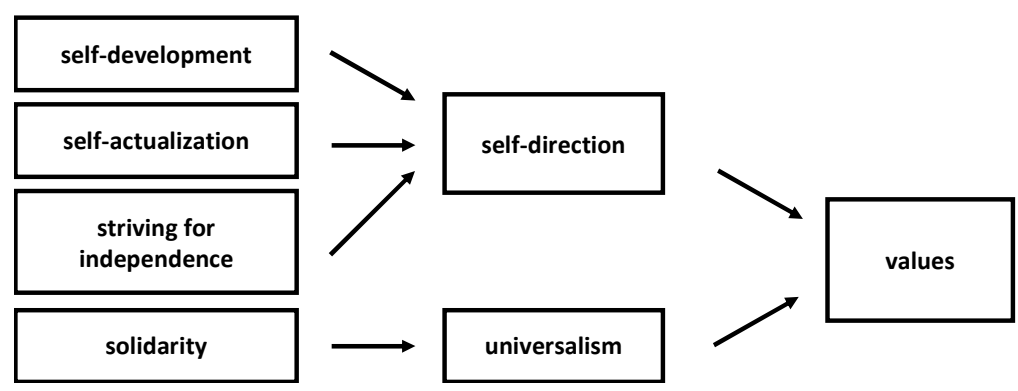

Figure 1. Motives for setting up a business in Poland

Source: own elaboration.

The first group of motives was identified as self-direction values of the respondents open to the idea of setting up a business. Respondents mentioned their striving for selfdevelopment, self-actualisation, or independence. "In five years, I would like to have my own firm. I would like to have something on my own and not to be forced to look for different jobs, because this can be different and difficult, as being on my own is being on my own" (Respondent no. 24). Those values were categorised by Schwartz (1994, p. 31). The second group of values are related to universalism. Within the analysed interviews, of special importance appeared solidarity and the possibility to help fellow nationals. This is consistent with the findings of Walton-Roberts and Hiebert (1997), who state that migrant firms may be a way of creating new workplaces for other migrants.

The second identified issue are the reasons for not setting up a business. Those reasons were also divided based on the degree of intention to start one's own business. The first and second order codes have been presented in Figure 2.

The first identified group of reasons was connected with the perceived need to build up the necessary social and intellectual capital, i.e. the need to graduate and the need to gain practical experience: "I wanted to graduate first. This is why I am studying Finance and Accounting - to know the details" (Respondent no. 10). This fits the findings of Caparrós Ruiz (2010), who indicate the need to build up the necessary social and intellectual capital before starting own business. Those reasons have been emphasised by migrants willing to start own businesses. The second group of reasons was categorised in accordance with Schwartz's human value structure (Schwartz, 1994). The respondents mentioned the lack of values like stability and security. The lack of stability in the analysed interviews included short residential status, young, age and parental responsibilities. "I don't know, I have not thought about it yet. I am too young for this, I'm only 20 years old. Maybe in a few years I will have my own company, however I did not think about it yet" (Respondent no. 32). On the other hand, the lack of security first and foremost included the legal status of the immigrant and the fact that a significant group of respondents was working illegally at the time of the interview. Values as motives for not setting up a business have been expressed by migrants generally willing to set up a business and those who have not thought about it yet. Finally, the third group of motives was summarised under a "migrant's mindset" label, which includes the perception of one's personality. "I have never thought about [becoming self-employed], because I am not a person who could do 
such a thing. I am not a person who would handle all of it" (Respondent no. 27). Considering Holland's theory of career choices, one must fit or, at least, be close to the enterprising personality type (Holland, 1997). Furthermore, the mindset incudes the perception of possible benefits or their lack and the perception of need to set up a business: "for now, it is not necessary, but it may become helpful in the future" (Respondent no. 29).

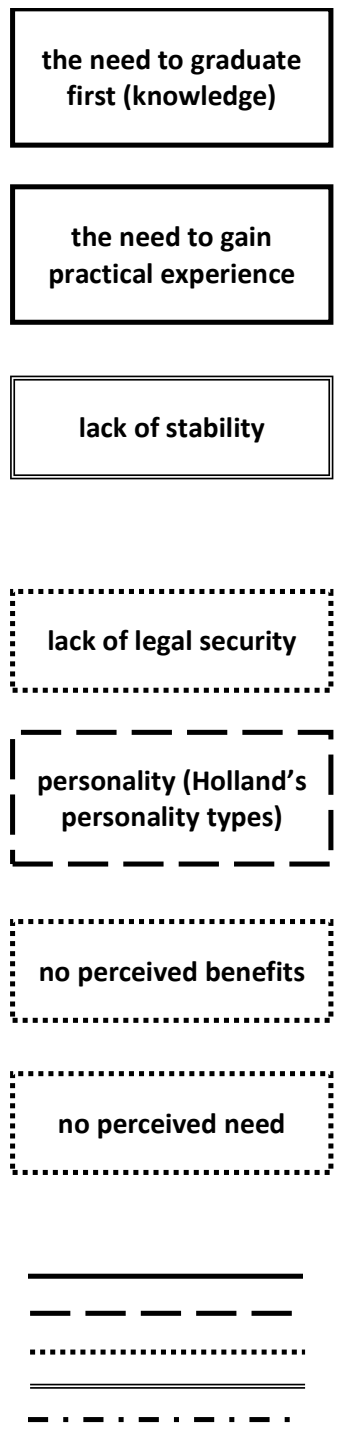

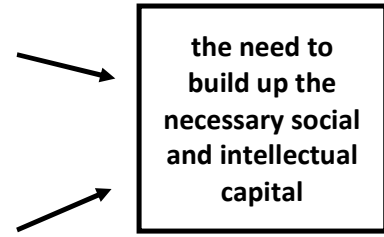
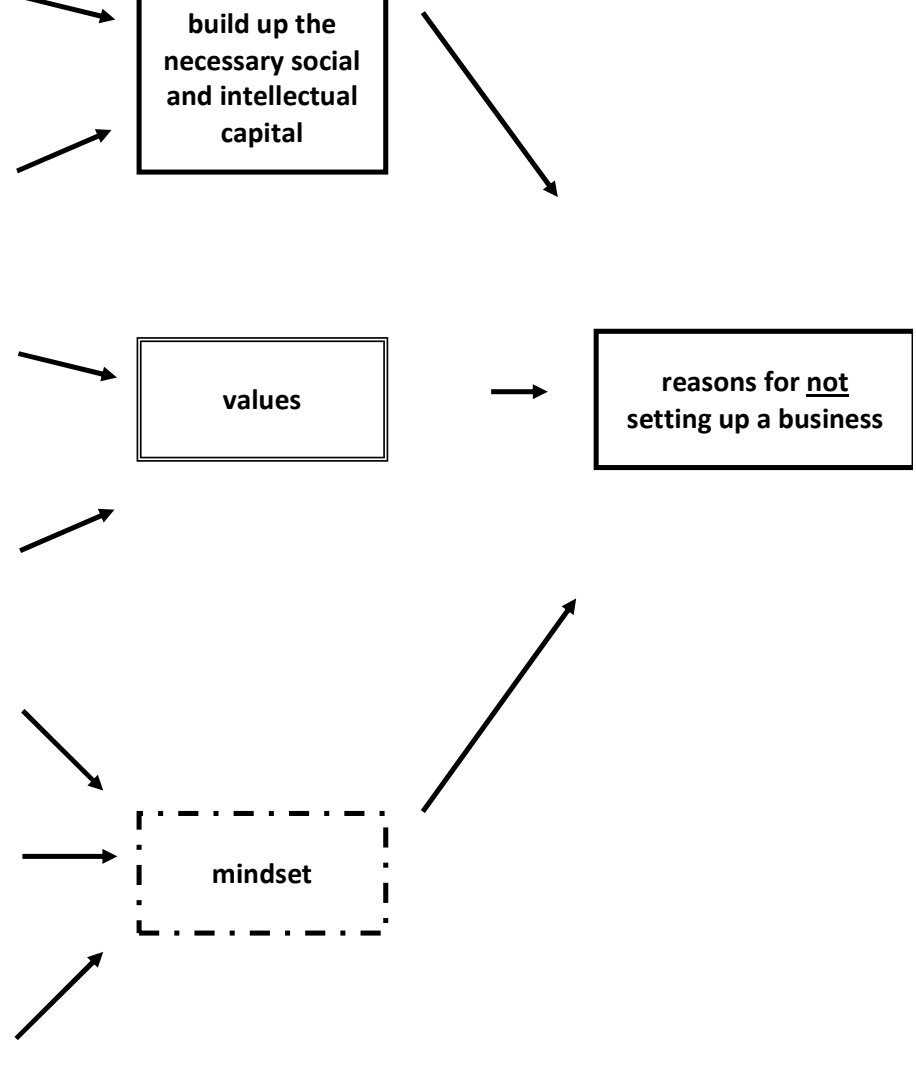

Willing to start a business Not willing to start a business Have not thought about starting a business Willing and those, who have not thought about starting a business Not willing and those, who have not thought about starting a business

Figure 2. Motives for not setting up a business in Poland Source: own elaboration.

The third selected element are the perceived barriers for setting up a business, presented in Figure 3. The perception of barriers was also analysed including different degrees of intention to set up own business. 

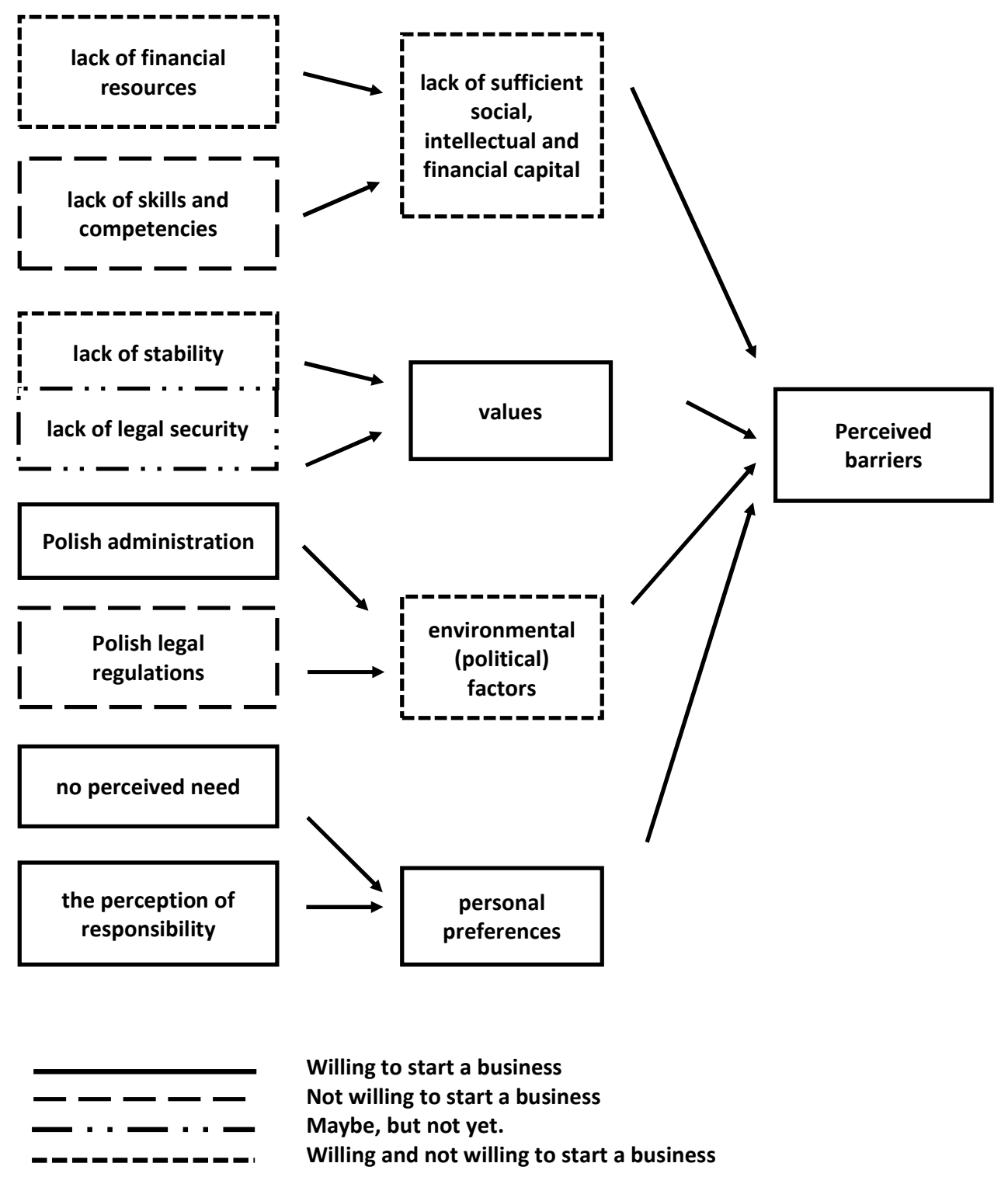

Willing to start a business
Not willing to start a business
Maybe, but not yet.
Willing and not willing to start a business

Figure 3. Perceived barriers for setting up a business in Poland Source: own elaboration.

Although some of the categories overlap with the presented reasons for not setting up a business, it seems necessary to present them also in the category of barriers - as some respondents pointed to them - without wholesale dismissing the idea of setting up a business now or in the foreseeable future.

The first group of barriers can be captured under the label of insufficient social, intellectual, and financial capital. This group of barriers was mentioned regardless of the 
intent to set up a business. The respondents highlighted the lack of necessary skills and competencies, especially linguistic. As most of the respondents would consider opening a business in services, as shown by Rueda-Armengot and Peris-Ortiz (2012), the financial barrier was also mentioned very often: "You need money if you want to have your own company" (Respondent no. 33). The second group of barriers are connected to values and, once again, includes the lack of stability and legal security. The lack of stability and security partially results from the financial situation of migrants, but also from the legal status of immigrants: "I could [start my own business], but as I am a foreigner I would have to pay high taxes, which in the beginning would be difficult" (Respondent no. 37). The lack of stability is also connected to the level of responsibility of an entrepreneur and the fact that the success of a company often depends on external factors: "I have always wanted to start my own business but this is a big responsibility. Whether the business will be successful depends not only on how much time you put into it, but it also depends on external factors. I've always wanted to have a hairdresser's salon, because I enjoy doing haircuts. Once, when I told my mother I wanted to become a hairdresser, she told me to study something normal, so I became a nurse" (Respondent no. 17). The third group of barriers is connected to environmental factors and includes complicated administration and legal regulation. These barriers have also been mentioned regardless of the intention to become entrepreneurial. However, as stated by Respondent no. 15, one can overcome these barriers. Finally, the fourth group of barriers includes personal preferences: the perceived need (or its lack) of becoming an entrepreneur and the perception of responsibility, as mentioned by Respondent no. 17. These barriers were mentioned by respondents generally willing to become entrepreneurial.

The conducted interviews showed that only one respondent had his own business. However, most of the respondents did not think about opening up their own businesses prior to the interview. There may be several reasons for this, considering the different answers given by the respondents, but also the previously conducted research. Firstly, considering the influence of personal-level variables, scholars established that entrepreneurship education has a greater effect on women's self-efficacy and, through this, on intentions (Shapero \& Sokol, 1982; Wilson et al., 2007). Secondly, as stated by Leicht et al. (2012), enterprises are started by migrants who have lived in the new country for more than 15 years. With small exceptions, most of the migrants interviewed for the purpose of this study have been in Poland for a much shorter time. Most arrived one year before the interview. The respondents directly stated they have not been in Poland long enough to think about becoming self-employed. The reason for a low interest in entrepreneurship among the migrants may be the consequence of the fact that, in general, people who decide to become independent are those with a stable status in Poland and with permanent residency rights (Andrejuk 2017b). Thus, the interviewed respondents do not have the necessary knowledge about administrative and legal aspects of starting own business. Moreover, in connection to the legal status of the migrants, we should again indicate that a major part of the respondents worked without the necessary legal permission. Another reason for the low willingness among immigrants to start their own business might be limited financial resources, which was also confirmed by the respondents in the study. Limited access to bank loans was identified as a barrier by Leicht et al. (2009). 
Considering the findings by Andrejuk (2017b), the fact that Ukrainians are the largest immigrant group in Poland, and that in the last years the influx of immigrants from the Ukraine has grown dynamically, the phenomenon of migrant entrepreneurship may become more prevalent in Poland. Furthermore, as stated by Caparrós Ruiz (2010), the growth of the human, financial, and social capital motivates entrepreneurship; especially human capital highly influences the competitive advantage of a company, but also that of a region (Zygmunt, 2020). This may be a positive indicator for future entrepreneurial activities. Some of the respondents started studying in Poland, which will raise their intellectual and social capital.

Research conducted in the Opole region completes the existing knowledge and research gap within migrant entrepreneurship research, especially in regard to the intention to become entrepreneurial. The innovative approach to the subject relies, among other things, on the fact that researchers in Poland mainly studied migrants who already have own businesses. These studies were conducted among the Vietnamese community in Warsaw and the surrounding area (Andrejuk, 2017a; Brzozowska, 2015), the Ukrainian community (Andrejuk, 2017a), and the Krakow-based Ukrainian entrepreneurs (Brzozowski 2019). However, these were conducted in large cities that provide greater opportunities for the development of the company. Research conducted in the Opolskie Voivodeship differs from previous analyses, as it included respondents who work and live not only in the region's capital but also in smaller cities and suburbs. Moreover, this region is a rather specific area of research because, firstly, it is a region that is aging and depopulating (Heffner, Klemens, \& Solga, 2019; Rokita-Poskart, 2016). Secondly, it is also a peripheral voivodship, located between two large agglomerations - Wroclaw and Katowice - with an average entrepreneurship rate (Zakrzewski \& Skowrońska, 2019). Furthermore, research shows that due to economic growth, there are differences between Polish regions in entrepreneurial activities (Zygmunt, 2018).

\section{CONCLUSIONS}

The paper contributes to the research on the entrepreneurial intentions of migrants in a specific under-investigated segment of the migrant population working in elderly care. The research problem was how the intention to become entrepreneurial influences the perceived barriers and hindrances of becoming self-employed. Firstly, research-related results showed that the vast majority reject the idea of starting their own business or never even thought about such a possibility. Respondents indicated financial barriers, legal status, language skills, and parental status as the main barriers for entrepreneurship among migrants. Nevertheless, as indicated by the one actually self-employed respondent, one can overcome the legal and administrational barriers. Secondly, as to the influence of the degree of intent to become self-employed, we observed such tendencies as the fact that the lack of sufficient social and intellectual capital as a motive for not setting up a business was indicated generally by those willing to become entrepreneurial, while the mindset characterised those who were unwilling or have not thought about becoming entrepreneurial. However, these tendencies require further testing. Research-related results also present some positives. A significant group of respondents stated that they would be willing to become self-employed, even if not in the near future. Furthermore, those open to the idea of self-employment do not necessarily plan to remain in the care sector, as for 
some, the current employment in the care sector is of a temporary nature. However, this may allow hope for an increase in migrant entrepreneurship in the coming years also in other sectors, not necessarily in the care sector, such as construction (Hawrysz, 2017) or retail (Kozel et al., 2017). The respondents open to the idea of entrepreneurship perceived their own business as a form of self-development and self-realisation, a way to help compatriots, or a possibility of filling a market gap.

Although the conducted research was of exploratory nature, the results have important theoretical implications, as it reveals the moderate willingness to start one's own business in Poland among migrants - while not excluding it completely - thus giving an insight into entrepreneurial tendencies of migrants. The interviewed migrants named a set of barriers which hindered or discouraged them from becoming self-employed, including the financial barrier, the lack of sufficient language skills, or their current legal status. The conducted research has important practical implications. As already mentioned, research has shown that migrant entrepreneurship may be a motor for economic development ( $\mathrm{Nel}$ \& Abdullah, 2015). Thus, the results are of great importance for decision-makers. A positive conclusion of the conducted study may be that a significant group of immigrants would consider starting their own businesses in Poland. However, in order for this to happen, the barriers perceived by the immigrants must be addressed and removed. The possible solutions would be firstly to further simplify the legal and administrative procedures the immigrants need to face or to develop a program for raising awareness and competence in contacting and handling Polish administration. Secondly, business environment units could organise special actions targeting immigrants and popularising the idea of entrepreneurship. Ponting towards sociopolitical implications, it may be time in Poland to start thinking about migrants as potential entrepreneurs and not only cheap labour force. Moreover, a significant group of immigrants who have not thought about setting up a business suggests that information and incentives for setting up businesses should be increased. Research shows that there is a large group of immigrants who can be acquired or lost in the context of entrepreneurial potential. Nonetheless, we should note that becoming self-employed is connected to financial and non-financial costs a migrant must carry, so it may not be the optimal solution for every person.

There are three groups of important factors for becoming self-employed: migrants' economic capital (e.g. having the capital to invest, having previous entrepreneurial experiences from the home country), cultural capital (e.g. bilingualism, knowledge of the host country's market), and social capital (e.g. having a network of contacts, friends, and family in the country of immigration) (Zapata-Barrero \& Rezaei, 2019). Immigrationfriendly policies and infrastructures such as governmental support networks are also important (Osaghae \& Cooney, 2019).

Several possible future research areas can be indicated as a result of the above research study. In the Polish context, it seems very important to conduct a comparative analysis between immigrants from EU countries and non-EU countries. Due to legal differences, especially regarding the administrative and legal procedures connected with setting up own business, such comparison could show important differences. Furthermore, due to the fact that the study was conducted only on immigrants from the care sector, future research should verify the information and conduct a similar study among representatives of other sectors. It may be the case that the sector the studied migrants are employed in 
is influences their entrepreneurial tendencies. The above study has some limitations. Due to its qualitative nature, the presented results cannot be treated as representative. Thus, one of the possible future analyses would be to conduct quantitative, representative research and investigate whether the length of stay influences the entrepreneurial tendencies or whether professional experience impacts the willingness to set up own business. Moreover, the question remains whether plans regarding the future stay in Poland affects the willingness to start own business. This questions requires a quantitative approach, which may nevertheless be difficult due to the nature of the research sample and difficulties that may arise when trying to determine the population and reach individual respondents. The results of the above study indicate some tendencies about those relations. Although we may say it only with great caution, the migrants that came to Poland in the last months or within the last few years were not that eager to start own businesses; with the exception of respondents with the student status. Regarding the potential influence of the question of migrants' future plans and their effect on entrepreneurial tendencies, most of the interviewed immigrants - irrespective of their willingness to start own businesses declared that they would like to stay in Poland and the Opole Voivodeship. Thus, it does not seem of relevance to the issue in question. However, such statements require a quantitative approach and hypothesis testing. Although the results are not representative, due to their exploratory nature they are an important starting point for future analysis and already at this point - include important practical implications. The results of this exploratory research should be treated with attention, as the influx of immigrants to Poland is expected to increase and problems signalled in this study will only gain in importance.

\section{REFERENCES}

Achidi Ndofor, H., \& Priem, R. L. (2011). Immigrant entrepreneurs, the ethnic enclave strategy, and venture performance. Journal of Management, 37(3), 790-818.

Aliaga-Isla, R., \& Rialp, A. (2013). Systematic review of immigrant entrepreneurship literature: previous findings and ways forward. Entrepreneurship and Regional Development, 25(9-10). 819-844. https://doi.org/10.1080/08985626.2013.845694

Andrejuk, K. (2017a). Przedsiębiorcy ukraińscy w Polsce Struktura i sprawstwo w procesie osiedlenia. Warszawa: IFiS PAN.

Andrejuk, K. (2017b). Self-employed migrants from EU Member States in Poland: differentiated professional trajectories and explanations of entrepreneurial success. Journal of Ethnic and Migration Studies, 43(4), 560-577. https://doi.org/10.1080/1369183x.2016.1249050

Baker, M., \& Benjamin, D. (1994). The performance of immigrants in the Canadian labor-market. Journal of Labor Economics, 12(3), 369-405. https://doi.org/0.1086/298349

Bird, B. (2015). Entrepreneurial intentions research: A review and outlook. International Review of Entrepreneurship, 13(3), 143-168.

Blume, K., Ejrnæs, M., Nielsen, H.S., \& Würtz, A. (2009). Labor market transitions of immigrants with emphasis on marginalization and self-employment. Journal of Population Economics, 22(4), 881-908. https://doi.org/10.1007/s00148-008-0191-x

Bolzani, D., \& Boari, C. (2018). Evaluations of export feasibility by immigrant and non-immigrant entrepreneurs in new technology-based firms. Journal of International Entrepreneurship, 16(2), 176-209. 
Borjas, G.J. (1991). National origin and the skills of immigrants in the postwar period. Retrieved from https://ideas.repec.org/h/nbr/nberch/6904.html on September 15, 2019.

Borjas, G.J. (1994). The economics of immigration. Journal of Economic Literature, 32(4), 1667-1717.

Bruquetas-Callejo, M. (2020). Long-Term Care Crisis in The Netherlands and Migration of Live-in Care Workers: Transnational Trajectories, Coping Strategies and Motivation Mixes. International Migration, 58(1), 105-118. https://doi.org/10.1111/imig.12628

Brzozowska, A. (2015). Przedsiębiorczość imigrantów wietnamskich w Polsce (unpublished PHD thesis). Warsaw. Retrieved from http://depotuw.ceon.pl/handle/item/1206 on October 8, 2019.

Brzozowski, J. (2008). Brain drain or brain gain? The new economics of brain drain reconsidered. The New Economics of Brain Drain Reconsidered (October 22, 2008)). https://doi.org/10.2139/ssrn.1288043

Brzozowski, J. (2017). Immigrant Entrepreneurship and Economic Adaptation: A Critical Analysis. Entrepreneurial Business and Economics Review, 5(2), 159-176. https://doi.org/10.15678/eber.2017.050209

Brzozowski, J. (2019). Przedsiębiorczość imigrantów w Krakowie - stan obecny i perspektywy rozwoju. UEK, Kraków: Obserwatorium Wielokulturowości i Migracji.

Brzozowski, J., Cucculelli, M., \& Surdej, A. (2017). The determinants of transnational entrepreneurship and transnational ties' dynamics among immigrant entrepreneurs in ICT sector in Italy. International Migration, 55(3), 105-125.

Brzozowski, J., \& Pędziwiatr, K. (2014). Analiza procesu integracji imigrantów w Małopolsce. In: E. Pindel (Ed.), Imigranci w Małopolsce. Między integracjq, asymilacjq, separacjq, marginalizacjq (pp.117-240). Krakow: Akademia Ignatianum.

Caparrós Ruiz, A. (2010). Self-employment or paid employment as the first job: Evidence from Spain by nationality. International Journal of Social Economics, 37(12), 951-969.

Chaganti, R., \& Greene, P.G. (2002). Who are ethnic entrepreneurs? A study of entrepreneursapos; ethnic involvement and business characteristics. Journal of Small Business Management, 40(2), 126-143.

Chammartin, G. (2008). Migration, Gender Equality and Development (Paper presented at the International Conference on Gender, Migration, Ration and Development: Seizing Opportunities, Upholding Rights). Manila, Phillipines. Retrieved from academia.edu on September 10,2019.

Charmaz, K. (2006). Constructing grounded theory: A practical guide through qualitative analysis. Sage.

Chiswick, B.R., \& Miller, P.W. (2009). The international transferability of immigrants' human capital. Economics of Education Review, 28(2), 162-169.

Chrysostome, E. (2010). The success factors of necessity immigrant entrepreneurs: In search of a model. Thunderbird International Business Review, 52(2), 137-152.

Constant, A., \& Zimmermann, K. F. (2006). The making of entrepreneurs in Germany: Are native men and immigrants alike? Small Business Economics, 26(3), 279-300.

Creswell, J.W., \& Miller, D.L. (2000). Determining validity in qualitative inquiry. Theory into Practice, 39(3), 124-130. https://doi.org/10.1207/s15430421tip3903_2

Curci, R., \& Mackoy, R. (2010). Immigrant business enterprises: A classification framework conceptualization and test. Thunderbird International Business Review, 52(2), 107-121.

Czerniejewska, I. (2014). „Migranci aktywni zawodowo” czy „zagraniczni przedsiębiorcy”? Raport z badań. Instytut Spraw Publicznych. 
Dang, C.-M., \& Harima, A. (2020). Dual Embeddedness and Entrepreneurial Activities of SecondGeneration Ethnic Entrepreneurs: Multiple Case Studies with Vietnamese Entrepreneurs in Germany. Journal of Entrepreneurship and Innovation in Emerging Economies, 6(1), 84-113. https://doi.org/10.1177/2393957519887554

Elo, M. (2016). Typology of diaspora entrepreneurship: case studies in Uzbekistan. Journal of International Entrepreneurship, 14(1), 121-155.

Evans, M. D.R. (1989). Immigrant Entrepreneurship - Effects of Ethnic Market-Size and Isolated Labor Pool. American Sociological Review, 54(6), 950-962. https://doi.org/10.2307/2095717

Fairlie, R.W. (2008). Estimating the contribution of immigrant business owners to the US economy. SBA Office of Advocacy. Retrieved from https://people.ucsc.edu on September 10, 2019.

Fairlie, R.W., \& Lofstrom, M. (2015). Immigration and entrepreneurship. In B.R. Chiswick \& P.W. Miller (Eds.), Handbook of the economics of international migration (pp. 877-911). Elsevier.

Fraser, S. (2006). Finance for Small and Medium-Sized Enterprises: Comparisons of Ethnic Minority and White Owned Businesses (Research Report prepared for the Department for Business Enterprise and Regulatory Reform). Retrieved from http://www.bis.gov.uk/files/file39925.pdf on September 9, 2019.

Glinka, B., \& Brzozowska, A. (2015). Immigrant Entrepreneurs: in Search of Identity. Entrepreneurial Business and Economics Review, 3(3), 51-76. https://doi.org/10.15678/eber.2015.030304

Glover, C., \& Sim, L. (2002). Entrepreneur Immigrant Survey: A Mail Survey of Entrepreneur Immigrants in Vancouver, Canada, Post-Terms and Conditions Removal. Strategic Research and Review, $\mathrm{ClC}$, and International Consortium for Venture Expertise. University of Victoria, Ottawa.

Goel, K., \& Penman, J. (2015). Employment experiences of immigrant workers in aged care in regional South Australia. Rural and Remote Health, 15(1), 14.

Gorny, A., \& Napierała, J. (2016). Comparing the effectiveness of respondent-driven sampling and quota sampling in migration research. International Journal of Social Research Methodology, 19(6), 645-661.

Hall, K., Needham, C., \& Allen, K. (2019). Micro entrepreneurship in the care sector: motives, values and practices. Voluntary Sector Review, 10(3), 311-328.

Hanson, G.H. (2006). Illegal migration from Mexico to the United States. Journal of Economic Literature, 44(4), 869-924.

Hawrysz, L. (2017). Environmental aspects of csr reporting in Polish construction sector enterprices listed on the warsaw stock exchange. Proceedings of the International Multidisciplinary Scientific GeoConference Surveying Geology and Mining Ecology Management, SGEM, 281-286.

Heckathorn, D.D. (1997). Respondent-driven sampling: A new approach to the study of hidden populations. Social Problems, 44(2), 174-199. https://doi.org/10.1525/sp.1997.44.2.03x0221m

Heffner, K., Klemens, B., \& Solga, B. (2019). Challenges of Regional Development in the Context of Population Ageing. Analysis Based on the Example of Opolskie Voivodeship. Sustainability, 11(19), 5207.

Holland, J.L. (1997). Making vocational choices: A theory of vocational personalities and work environments. Psychological Assessment Resources.

Honig, B. (2018). Exploring the intersection of transnational, ethnic, and migration entrepreneurship. Journal of Ethnic and Migration Studies, 1-17.

Hughes, K.D. (2003). Pushed or pulled? Women's entry into self-employment and small business ownership. Gender, Work \& Organization, 10(4), 433-454.

Hugo, G. (2009). Care Worker Migration, Australia and Development. Population Space and Place, 15(2), 189-203. https://doi.org/10.1002/psp.534 
Ilhan-Nas, T., Sahin, K., \& Cilingir, Z. (2011). International ethnic entrepreneurship: Antecedents, outcomes and environmental context. International Business Review, 20(6), 614-626.

Kloosterman, R., \& Rath, J. (2003). Immigrant entrepreneurs: Venturing abroad in the age of globalization. Oxford/New York: Berg/University of New York Press.

Kloosterman, R.C. (2010). Matching opportunities with resources: A framework for analysing (migrant) entrepreneurship from a mixed embeddedness perspective. Entrepreneurship and Regional Development, 22(1), 25-45. https://doi.org/10.1080/08985620903220488

Kozel, R., Hawrysz, L., Vilamová, Š., \& Hys, K. (2017). Mystery e-mail/website customer service. A case study of retail companies. Scientific Papers of the University of Pardubice, Series D: Faculty of Economics and Administration, 24(40), 95-107.

Krueger, N.F. (2017). Entrepreneurial intentions are dead: Long live entrepreneurial intentions. In Revisiting the entrepreneurial mind (pp. 13-34). Springer.

Le, A.T. (2000). The determinants of immigrant self-employment in Australia. International Migration Review, 34(1), 183-214. https://doi.org/10.2307/2676017

Leicht, R., Di Bella, J., Langhauser, M., Leiß, M., Philipp, R., Werner, L., Volkert M., Berwing, S., \& Tur Castelló, J. (2012). Schöpferische Kraft der Vielfalt: Zugewanderte und ihre Unternehmen. Mannheim (Report). Retrieved from https://madoc.bib.uni-mannheim.de on September 8, 2019.

Leicht, R., \& Welter, F. (2009). Selbständig integriert?: Studie zum Gründungsverhalten von Frauen mit Zuwanderungsgeschichte in Nordrhein-Westfalen. In: Ministerium für Generationen, Familie, Frauen und Integration des Landes Nordrhein-Westfalen, Mannheim. Retrieved from http://www.institut-fuer-mittelstandsforschung.de on 7 September, 2019.

Light, I., \& Gold, S. (2000). Ethnic Economies. Emerald Publishing.

Liñán, F., \& Fayolle, A. (2015). A systematic literature review on entrepreneurial intentions: citation, thematic analyses, and research agenda. International Entrepreneurship and Management Journal, 11(4), 907-933.

Lofstrom, M. (2014). Immigrants and entrepreneurship. IZA World of Labor. Retrieved from wol.iza.org on 6 September 2019.

Lutz, H., \& Palenga-Möllenbeck, E. (2011). Care, gender and migration: Towards a theory of transnational domestic work migration in Europe. Journal of Contemporary European Studies, 19(3), 349-364.

Martin, S., Lowell, B.L., Gozdziak, E.M., Bump, M., \& Breeding, M.E. (2009). The role of migrant care workers in aging societies (Report on Research Findings in the United States). Institute for the Study of International Migration, Walsh School of Foreign Service, Georgetown University, Washington DC.

Nel, P., \& Abdullah, M. (2015). An exploratory study of Immigrant entrepreneurs in Malaysia regarding their business success and prospects in the small retail business sector. Asia Pacific Journal of Business and Management, 6(1/2), 18-31.

Nestorowicz, J. (2013). Do Networks Do the Works? Towards Recognising (and Solving) a MigrationEntrepreneurship Conundrum. Central Eastern European Migration Review, 2(2).

Neville, F., Orser, B., Riding, A., \& Jung, O. (2014). Do young firms owned by recent immigrants outperform other young firms? Journal of Business Venturing, 29(1), 55-71. https://doi.org/10.1016/j.jbusvent.2012.10.005

Osaghae, O.-G., \& Cooney, T.M. (2019). Exploring the relationship between immigrant enclave theory and transnational diaspora entrepreneurial opportunity formation. Journal of Ethnic and Migration Studies, 1-20. 
Pelzelmayer, K. (2016). Places of difference: narratives of heart-felt warmth, ethnicisation, and female care-migrants in Swiss live-in care. Gender Place and Culture, 23(12), 1701-1712. https://doi.org/10.1080/0966369x.2016.1249351

Pires, A. J.G. (2015). Brain drain and brain waste. Journal of Economic Development, 40(1), 1-34.

Rahman, M.M. (2018). Beyond labour migration: The making of migrant enterprises in Saudi Arabia. International Sociology, 33(1), 86-106. https://doi.org/10.1177/0268580917745770

Raijman, R., \& Tienda, M. (2000). Immigrants' pathways to business ownership: A comparative ethnic perspective. International Migration Review, 34(3), 682-706. https://doi.org/10.2307/2675941

Ram, M., \& Smallbone, D. (2003). Policies to support ethnic minority enterprise: the English experience. Entrepreneurship and Regional Development, 15(2), 151-166. https://doi.org/10.1080/0898562032000075177

Rokita-Poskart, D. (2016). Educational migration and the labour market. Czech Journal of Social Sciences Business and Economics, 5(1), 6-18.

Rueda-Armengot, C., \& Peris-Ortiz, M. (2012). The emigrant entrepreneur: a theoretical framework and empirical approximation. International Entrepreneurship and Management Journal, 8(1), 99-118. https://doi.org/10.1007/s11365-010-0164-x

Rugolotto, S., Larotonda, A., \& van der Geest, S. (2017). How migrants keep Italian families Italian: badanti and the private care of older people. International Journal of Migration Health and Social Care, 13(2), 185-197. https://doi.org/10.1108/ijmhsc-08-2015-0027

Saxenian, A. (2002). Silicon valley's new immigrant high-growth entrepreneurs. Economic Development Quarterly, 16(1), 20-31. https://doi.org/10.1177/0891242402016001003

Schwartz, S. H. (1994). Are there universal aspects in the structure and contents of human values?. Journal of Social Issues, 50(4), 19-45.

Schwiter, K., Strauss, K., \& England, K. (2018). At home with the boss: Migrant live-in caregivers, social reproduction and constrained agency in the UK, Canada, Austria and Switzerland. Transactions of the Institute of British Geographers, 43(3), 462-476. https://doi.org/10.1111/tran.12235

Shapero, A., \& Sokol, L. (1982). The social dimensions of entrepreneurship. Encyclopedia of Entrepreneurship, 72-90.

Shinnar, R.S., \& Young, C.A. (2008). Hispanic immigrant entrepreneurs in the las vegas metropolitan area: Motivations for entry into and outcomes of self-employment. Journal of Small Business Management, 46(2), 242-262. https://doi.org/10.1111/j.1540-627X.2008.00242.x

Solga, B., \& Kubiciel-Lodzińska, S. (2017). Poland: immigration instead of emigration. Transformation of the mobility model. In K. Soliman (Ed.), Vision 2020: Sustainable Economic development, Innovation Management, and Global Growth (pp. 797-810). Madrid: International Business Information Management Association.

Strauss, A., \& Corbin, J. (1994). Grounded theory methodology. Handbook of Qualitative Research, $17,273-285$.

Strauss, A., \& Corbin, J. M. (1997). Grounded theory in practice. Sage.

Teixeira, C., Lo, L., \& Truelove, M. (2007). Immigrant entrepreneurship, institutional discrimination, and implications for public policy: a case study in Toronto. Environment and Planning CGovernment and Policy, 25(2), 176-193. https://doi.org/10.1068/c18r

van Delft, H., Gorter, C., \& Nijkamp, P. (2000). In search of ethnic entrepreneurship opportunities in the city: a comparative policy study. Environment and Planning C-Government and Policy, 18(4), 429-451. https://doi.org/ 10.1068/c9873 
Van Hooren, F. (2010). When families need immigrants: The exceptional position of migrant domestic workers and care assistants in Italian immigration policy. Bulletin of Italian Politics, 2(2), 21-38.

Volery, T. (2007). Ethnic entrepreneurship: a theoretical framework. Handbook of Research on Ethnic Minority Entrepreneurship, 1, 30-41.

Waldinger, R.D., Aldrich, H., \& Ward, R. (1990). Ethnic entrepreneurs: Immigrant business in industrial societies (vol. 1). Sage Publications.

Walsh, K., \& O'Shea, E. (2010). The role of migrant care workers in ageing societies: report on research findings in the United Kingdom, Ireland, Canada and the United States. International Organization for Migration - IOM Migration Reserach Series, No. 41. Retrieved from https://aran.library.nuigalway.ie/handle/10379/3217 on October 25, 2019.

Walton-Roberts, M., \& Hiebert, D. (1997). Immigration, entrepreneurship, and the family: Indo-Canadian enterprise in the construction industry of Greater Vancouver. Canadian Journal of Regional Science, 20(1), 119-140.

Wilpert, C. (2003). Germany: from workers to entrepreneurs. Immigrant Entrepreneur, Venturing Abroad in the Age of Globalisation, 233-260. Berg, Oxford.

Wilson, F., Kickul, J., \& Marlino, D. (2007). Gender, entrepreneurial self-efficacy, and entrepreneurial career intentions: Implications for entrepreneurship education. Entrepreneurship Theory and Practice, 31(3), 387-406.

Yeates, N. (2010). The globalization of nurse migration: Policy issues and responses. International Labour Review, 149(4), 423-440. https://doi.org/10.1111/j.1564-913X.2010.00096.x

Zakrzewski, R., \& Skowrońska, A. (2019). Raport o stanie sektora małych $i$ średnich przedsiębiorstw $w$ Polsce. PARP, Warszawa. Retrieved from https://www.parp.gov.pl/storage/publications/pdf/2019_07_ROSS.pdf on September 28, 2019.

Zapata-Barrero, R., \& Rezaei, S. (2019). Diaspora governance and transnational entrepreneurship: the rise of an emerging social global pattern in migration studies. Journal of Ethnic and Migration Studies. https://doi.org/=10.1080/1369183X.2018.1559990

Zygmunt, A. (2020). Do Human Resources and the Research System Affect Firms' Innovation Activities? Results from Poland and the Czech Republic. Sustainability 12(6), 1-14. https://doi.org/10.3390/su12062519

Zygmunt, J. (2018). Does level of economic growth matter in spatial diversity in entrepreneurial activity in a transition economy? A case of Poland. Proceedings of the 32nd International Business Information Management Association Conference (pp. 6999-7006). IBIMA. 


\section{Authors}

The contribution share of authors is equal and amounted to $50 \%$ each of them.

\section{Jolanta Maj}

Assistant professor at the Opole University of Technology, Faculty of Economics and Management. She holds a Ph.D. degree in political science. Her research interests are issues of diversity management and corporate social responsibility.

Correspondence to: Jolanta Maj, PhD, Opole University of Technology, Faculty of Economics and Management, ul. Luboszycka 7, 45-036 Opole, Poland e-mail: j.maj@po.edu.pl

ORCID (1) http://orcid.org/0000-0001-5542-0713

\section{Sabina Kubiciel-Lodzińska}

Assistant professor at the Opole University of Technology, Faculty of Economics and Management. She holds a Ph.D. degree in economic science. Her research interests are issues of migration. Correspondence to: Sabina Kubiciel-Lodzińska, PhD, Opole University of Technology, Faculty of Economics and Management, ul. Luboszycka 7, 45-036 Opole, Poland e-mail: s.kubiciel@po.edu.pl ORCID (1) http://orcid.org/0000-0002-5465-6967

\section{Acknowledgements and Financial Disclosure}

The research was funded by the National Science Centre as part of the Miniature 1 competition based on agreement DEC-2017/01/X/HS4/00314.

\section{Copyright and License}

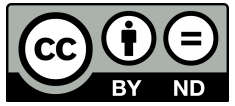

This article is published under the terms of the Creative Commons Attribution - NoDerivs (CC BY-ND 4.0) License http://creativecommons.org/licenses/by-nd/4.0/ 